\title{
Raspberry Pi 3 Linux SmartMirror megtervezése és megvalósítása
}

\author{
Nagy Ádám Károly \\ Mérnökinformatikus \\ Debreceni Egyetem, Informatikai \\ Kar \\ Debrecen, Magyarország \\ nagyadamkaroly@gmail.com
}

\author{
Beatrix Papp \\ London South Bank \\ University \\ School of Law and Social \\ Sciences, \\ London, United Kingdom \\ pappb@1sbu.ac.uk
}

\author{
Erdei Timotei István \\ Mechatronikai Tanszék \\ Debreceni Egyetem, Müszaki Kar \\ Debrecen, Magyarország \\ timoteierdei@eng.unideb.hu
}

\begin{abstract}
Absztrakt- Az innovációnak egyre fontosabb szerepe van a hazai márkák és cégek versenyképességének a megőrzésében. A multinacionális cégek ma már egyértelmúen ebben látják a sikerekhez vezető utat. Az innováció a legfontosabb hívó szó nem csak a Magyar hanem az egész európai gazdaságban. Egyre inkább eszmélnek rá a cégek, hogyha amennyiben a fejlesztésekre nem költenek nagyságrendekkel nagyobb pénzt akkor annál nagyobb lesz a lemaradás, például.

Magyarország eddig is jelentős eredményeket ért el az innováció területén. A digitális technológia szerepe és lehetőségei a társadalmi viszonyok alakításában, a jövő foglalkozásai, valamint a munkaerőpiac változása olyan tényezők, amelyek a nemzetgazdaság egészét átalakítják a következő időszakban.
\end{abstract}

Kulcsszavak- smartmirror, two-way mirror, Raspberry pi 3, innovatív, Linux, Pixel Os

\section{BEVEZTÖ}

Az IoT [9] világban élünk ahol egyre több háztartási eszköz csatlakozik az internetre. A hütő emailt küld, hogy vegyél tejet, a mosógép értesítést küld a telefonodra hogy lejárt a program. A telefonon számos olyan alkalmazás létezik, amin például a lámpák fel-le kapcsolgatását biztosítják különböző helységekben. Ezek pedig már nem a jövő, hanem a jelen kor eszközei.

A projekt kiválasztáskor az inovativitás és a költségtakarékosság voltak a fó szempontok, így esett a választás SmartMirror-ra azaz az intelligenstükörre.

A projekt alapját a Raspberry Pi 3 mini-pci adta. A Raspberry Pi 3 egyik komolyabb fejlesztése az integrált Broadcom BCM43438 chip. Az apró kiegészítő a 2,4 GHz-es tartományban müködő $802.11 \mathrm{~b} / \mathrm{g} / \mathrm{n}$ Wi-Fi mellett a Bluetooth 4.1-et és az alacsony energiaigényü BLE-t is támogatja, előbbi egyetlen antennával üzemel, így az elérhető maximális elméleti sávszélesség $150 \mathrm{Mbps}$ lehet [10]. Emellett az Ethernet port is megmaradt, így a vezetékes kapcsolatot preferálóknak sem kell kompromisszumot kötniük. A vezeték nélküli vezérlő integrálásának hála csökkenhet a Pi müködéséhez szükséges kábelek és/vagy különféle kiegészítők mértéke, nem szükséges külön megvásárolt adapterek alkalmazása. Az integrált Bluetooth vezérlőt számtalan módon lehet hasznosítani, olyan alapvető perifériák mellett, mint a billentyüzet/egér, például különféle szenzor egységek is használhatóak a géppel.

A korábbi modelltől, a Raspberry Pi 2-től, elsőre nem tünik soknak a különbségek viszont ha belegondolunk hogy az angol gyártó ragaszkodott az előző modell árához így a Pi 3 változatlanul $35 \$$-ért került értékesítésre. Ezzel az árral nehéz felvenni a versenyt a konkurencia cégeknek, ez az egyik fö oka a Raspberry sikerének[3]. A kutatás/fejlesztésnek a Debreceni Egyetem adott otthont [23].

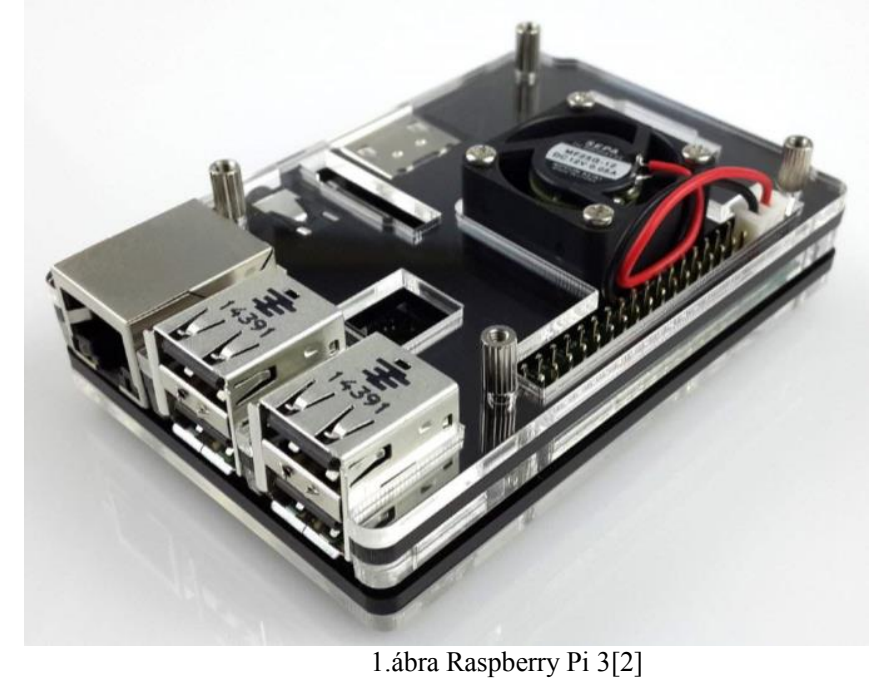

II. TERVEZÉSI SZEMPONTOK

Mindenekelőtt is szükség volt egy olyan váz létrehozására, amely viszonylag könnyü, de mégis masszívtartással rendelkezik, mert a falon történő rögzítés mellett, meg kell tartania egy régebbi típusú LCD monitort, aminek a súlya 2.1 kilogramm [11]. Így a választás egy lemezhajtogató gép által megmunkált lemezek összeillesztésével valósult meg. A projekthez elengedhetetlen volt egy detektív üveg lap. Ellene szólt még a magas költségek 
mellett az is, hogy ilyen kis méretben csakis külföldröl lett volna lehetőség beszerezni, így.

Alternatívaként egy speciális tükörfólia lett alkalmazva, amivel szinte ugyanazt a hatást lehet elérni.

\section{A VÁZ MEGÉPÍTÉSE}

A váz esetében $0,5 \mathrm{~mm}$ vastagságú fémlemez volt használva. Az 1x2m-es lemezből 95x100mm-es csíkokat lettek vágva, amelyekből készült el a $\mathrm{Z}$ profil. Az építkezés alapanyaga a $\mathrm{Z}$ profil acélszerkezete volt. Leginkább tetöhöz és falhoz szelemenként használják. Szelvénykialakítása különböző fülméretü, így egymásba forgatva külön toldó nélkül toldhatóak. Ennek a profilnak a magassága $55 \mathrm{~mm}$, a szárnya pedig $22 \mathrm{~mm}$. A rendelkezésre álló lemezhajlító tógéppel lettek hajtogatva.

A meglévő 1 méteres $Z$ profilok közül $2 \mathrm{db} 605 \mathrm{~mm}$-es hosszú lett vágva és ez a 2 db levágott lemez alkotja a függőleges oldalakat. A megmaradt $3 \mathrm{db}$ profil hossza, $365 \mathrm{~mm}$, melyek a vízszintes oldalakat alkotják.

A profilok 4-es csavarral vannak illesztve. $\mathrm{Az}$ összeillesztéséhez $6 \mathrm{db}$ sarok került felhasználásra. Az összeszerelést követően, a vázat, a legalsó vízszintes oldal közepéből, kivágásra került egy $150 \mathrm{~mm}$ x 20mm-es rész, a Raspberry Pi 3 számára.

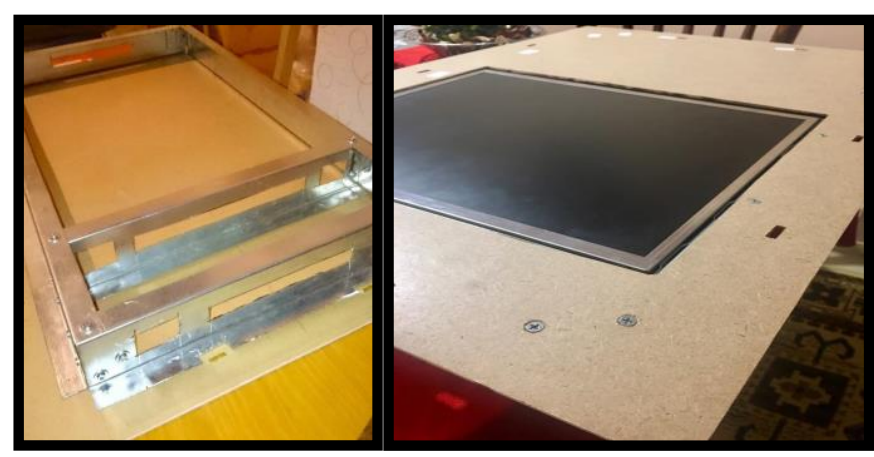

2.ábra Smart Mirror váz \& szerelt LCD monitor

Végezetül az alsó 2 vízszintes oldalra további 2-2 nyílás vágva, melyek 30x 25mm-es nagyságúak, ezek a rések a vezetékek helyét biztosítják, valamint a levegő hütéséről is gondoskodnak. A lemezek azon élei, melyek a vezetékekkel érintkeznek, müanyag borítással lettek lefedve. A vázhoz szerelt préselt lemez, süllyesztett fejü csavarokkal, valamint égésmentes ragasztóval lettek összeillesztve.

Az összeillesztést követően a pontos méretvétel után került ki vágásra az LCD monitor helye.

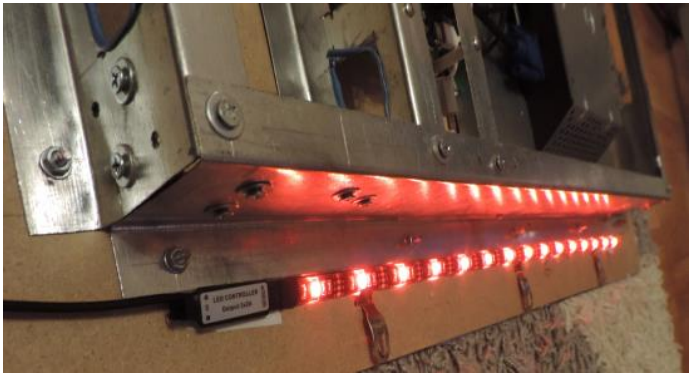

3.ábra Vázra szerelet LED csík
Miután az üveg a helyére került, a két függőleges oldalához távirányítással vezérelhető RGB 5050 LED csíkok kerültek felragasztásra [5]. A tükör lap alapját egy sima üveglap adja, amit egy tükör fóliával lett lefedve.

\section{SMARTMIRROR KAPCSOLÁS MEGTERVEZÉSE \& SZENZOROK ALKALMAZÁSA}

A Smart Mirror esetében, több a különböző szenzor is beépítésre került. Továbbá a be/ki kikapcsolást egy speciális töltőkábellel lett megoldva.

Szenzorok terén egy DHT-22 típusú hő és páratartalom mérö lett felhasználva, aminek a segítségével a tükörre tudjuk vetíteni a lakásban lévő aktuális hőmérsékletet valamint a páratartalmat. Ez, egy alacsony költségü digitális szenzor, amely kapacitív páratartalom-érzékelöt és termisztort használ a környező levegö mérésére [12].

A fentebb említett szenzor mellé került beszerelésre $2 \mathrm{db}$ PIR mozgásérzékelő szenzor is. A ma használatos mozgásérzékelök legnagyobb csoportját a passzív infravörös (Passive Infra Red = PIR) érzékelők adják. Népszerüségüket viszonylag alacsony áruknak valamint széles felhasználási lehetőségeiknek köszönhetik. Feladata, hogy a megfigyelt terület infravörös tartományba eső sugárzást, emberi testmelegből származó hősugárzást érzékelje, és egy optikai rendszer segítségével egy pontra fókuszálja. A fókuszpontban egy piroelektromos elven müködő szenzor található, amelynek célja, hogy a védett területen mozgó ember által kiváltott infrasugárzás szintjének - a környezet alap jelszintjéhez viszonyított - megváltozását villamos jelváltozássá alakítsa. A villamos jelek változását egy jelfeldolgozó áramkör kiértékeli és szükség esetén egy relé müködtetésével riasztást vált ki [13].

A passzív müködési elv az energiatakarékosságon kívül még egy előnnyel jár. Az infrák nem befolyásolják egymás müködését, ezért nincs semmi akadálya annak, hogy több érzékelő kerüljön felszerelésére egy helyiségen belül.
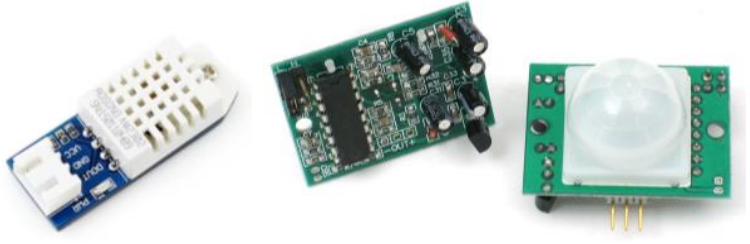

4.ábra Smart Mirror sensors - DHT-22 \& PIR [12][13]

Ha az első számú mozgásérzékelő bármilyen mozgást érzékel, akkor felkapcsolódik a LED szalag valamint az LCD monitor. Ez jelentős hő kibocsátás csökkentést jelent hosszútávon, mivel a monitor és a LED szalag a mozgásérzékelő hatására csupán egy percig maradnak bekapcsolt állapotban, ezután újra kikapcsolnak. Nem csak a monitor számára jelent ez a funkció hő kibocsátás csökkentést, hanem a Raspberry Pi 3 számára is.

Az ezze szükséges kapcsolás az ingyenesen elérhető és letölthető Fritzing -ben került megtervezésre [14]. 


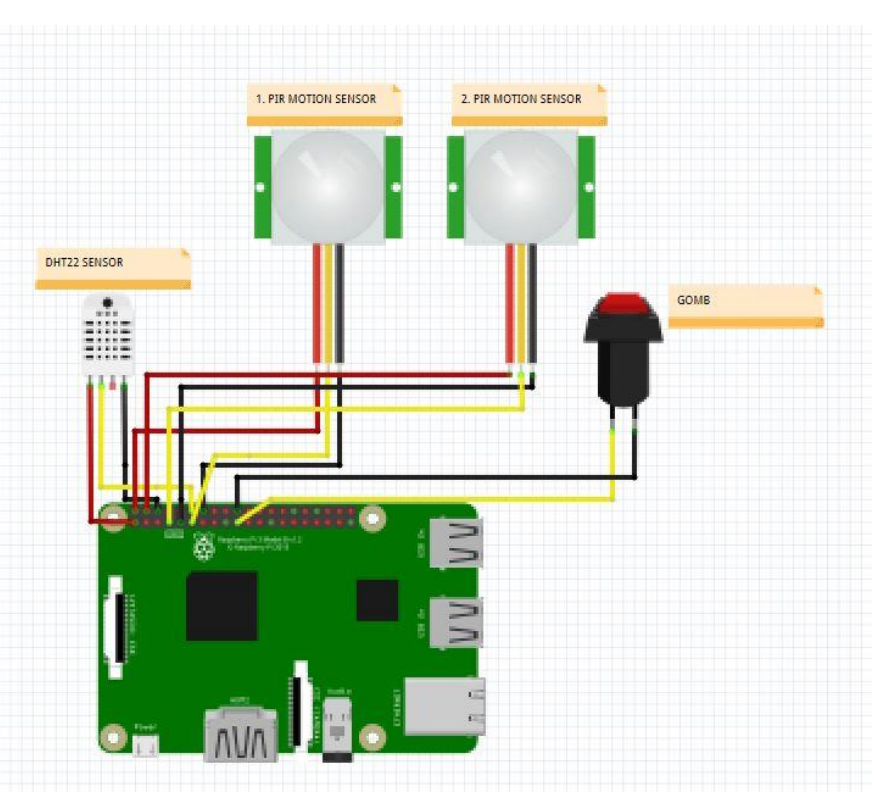

5.ábra Megtervezett kapcsolás

Ahogy az 5.ábrán is látszik az első számú mozgásérzékelőhöz tartozik egy nyomógomb is. Ennek segítségével tudjuk a LED szalagot ki és bekapcsolni. Ez sokat jelent nappal mivel ilyenkor nincs szükség a megvilágításra, ekkor a mozgásérzékelő csak a monitort szabályozza. Amint megnyomjuk a gombot a LED szalag is újra szabályozhatóvá, vezérelhetővé válik.

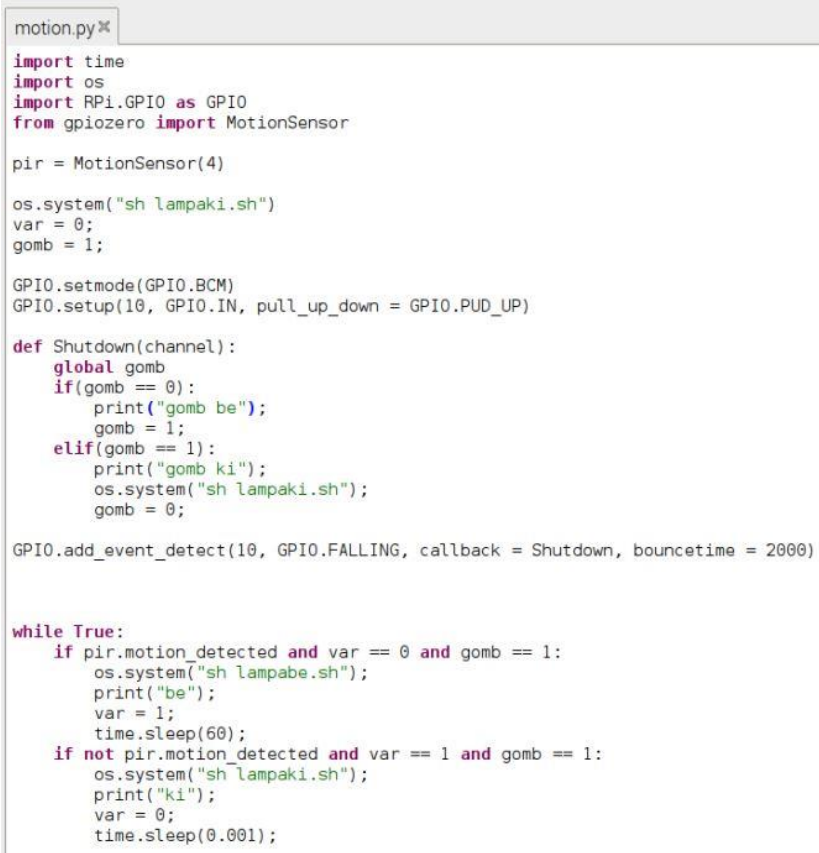

6.ábra mozgásérzékelő és nyomógomb programkód (részlet)
A programkódban látható, hogy két script futtatásával történik a LED sor ki/be kapcsolgatása. A „lampaki.sh” azt az usb port-ot kapcsolja ki, amibe a LED szalag van csatlakoztatva.

Fảjl Szerkesztés Keresés Beállitások Sủgo

sudo su <<EOF
echo $\Theta>$ /sys/bus/usb/devices/usb1/1-1/1-1:1.0/1-1-port2/power/pm_qos_no_power_off

7.ábra lampaki.sh forráskód

A ,lampabe.sh” script annyiban tér el a „lampaki.sh”-tól hogy, a megadott fájlba „1" illeszt így müködésbe lép a megadott usb port.

Fájl Szerkesztés Keresés Beállitások Súgo

sudo su <<EOF
echo $1 \gg /$ sys/bus/usb/devices/usb1/1-1/1-1:1.0/1-1-port2/power/pm_qos_no_power_off

8.ábra lampabe.sh forráskód

A második számú mozgásérzékelő a vázon egy olyan helyet kapott ahonnan csak egy bizonyos szögböl képes mozgást érzékelni. Ez azért is volt különösen fontos mivel ezzel a szenzorral tudjuk bekapcsolni valamint kikapcsolni a rádiót. Amint mozgást érzékel, egyből elindul egy rádió csatorna a beépített hangszórók segítségével.

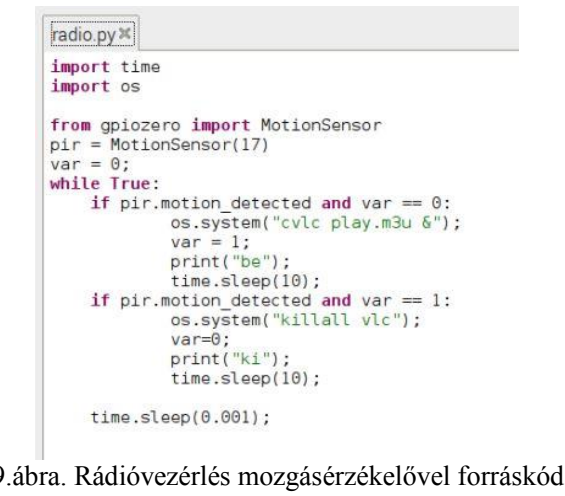

Ahogy a forráskódban is megjelenik, egy online stream fájl-t indít el VLC [15] lejátszón automatikusan. Ez folyamatosan futni fog mindaddig, míg újabb mozgást nem érzékel, (ez esetben akár kéz suhintást) ekkor egyből kikapcsol a rádió azaz kilép a lejátszóból. Ez a folyamat újra és újra ismétlődik.

\section{SMART MIRROR MODULOK ÖSSZEÁLLÍTÁSA ÉS ÖSSZEHANGOLÁSA}

A program, amely segítségével a beépített monitoron keresztül megjelennek a kívánt információk, Raspberry környezetbe került megírásra, Javascript alapon, és modulárisan épül fel Open-Source alapon [4]. A betöltésért a config.js fájl felel. Itt tudjuk beállítani, hogy milyen pozícióban, milyen sorrendben és, hogy mely modul szerepeljenek a kijelzőn. Ezek a modulok tartalmazzák külön-külön mindegyik információ blokk kódját.

$\mathrm{Az}$ indítás során a háttérben létrehoz egy websocket kapcsolatot a kiszolgálóval. Minden modul betöltődik a 
modulok mappából amit a config.js fájl engedélyez. A Smart Mirror modulok kiválasztása komoly végig gondolást igényelt, hiszen az adott funkciókról mi magunk dönthettünk, illetve a felhasznált szenzorokhoz mérten is kellett megválasztani.

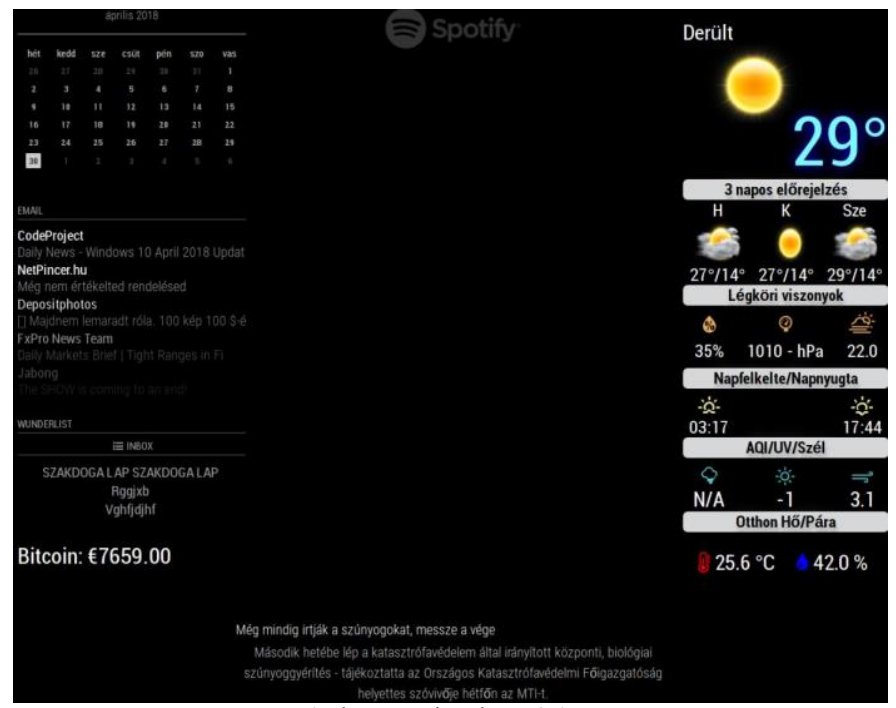

10.ábra MagicMirror 2.0 [4]

Az általános megjelenítendő információk között szerepelt, az időjárás előrejelzés, a hő és páratartalom, Bitcoin árfolyam, Spotify [4] és naptár is.

A CSS fájlokon több módosítást is történt, tagolt, jobban látható modulok. Egyesítésre került az aktuális kinti hőmérséklet, az időjárás előrejelzés és a napfelkelte/ napnyugta modul. Kibővítésre került a légköri viszonyokkal, az aqi/uv/szél mérésekkel valamint itt kapott helyett a DHT22 szenzor méréseinek értékei - név szerint Otthon Hő/Pára. Baloldalon található a naptár modul, de itt helyezkednek el a bejövő e-mailek is. Ez egy nagyon hasznos funkció, a saját erre a célra dedikált e-mail fiókkal került összekapcsolásra. Az állandó frissítés mellett, megjeleníti a legutóbbi öt bejövő emailemet. A következő modul egy ToDoList azaz feladatlista alkalmazással összekapcsolt modul.

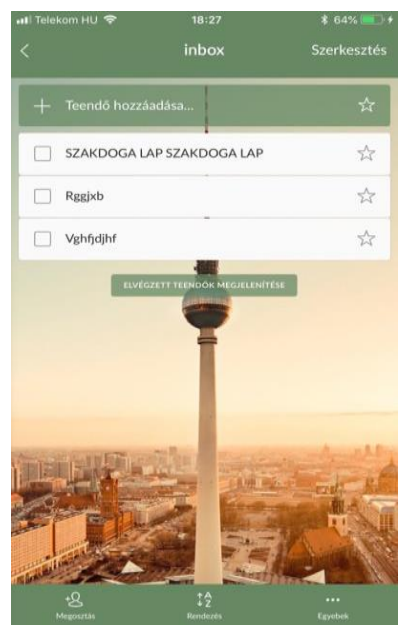

11.ábra Wunderlist nevü alkalmazás [15]
A WunderList [15] nevű alkalmazással tudunk teendőket hozzáadni a modulhoz. Emellett két nagyon jó előny is társúl hozzá, mégpedig hogy egy felhasználóhoz akár több telefont is tudunk csatlakoztatni ezáltal többen tudják testre szabni a modult valamint a másik kiemelendő előny pedig az hogy, prioritási sorrendet tudunk felállítani.

Kiegészítő modulként jelen van a Bitcoin [17] valuta aktuális értékét mutatja óránkénti frissítésben.

A tükrön található még három modul: egy Spotify [18], egy

YouTube Cast [19], valamint egy „Hírfolyam” modul. A hírfolyam modul megjelenítéshez az Index [20] nevü hírportál RSS funkciója lett beépítve a modulba. Ezáltal az éppen aktuális friss hírek szalagcímei és ezzel kapcsolatos rövid ismertetők jelennek meg a tükör felületén. Óránként tölti le a frisshíreket az Index oldaláról.

A másik két modul csak akkor látszódik, ha telefonnal vagy számítógéppel csatlakozunk a tükörhöz. A Spotify modul a Spotify Developer [18] fejlesztői oldalon keresztüli csatlakozással indul el.

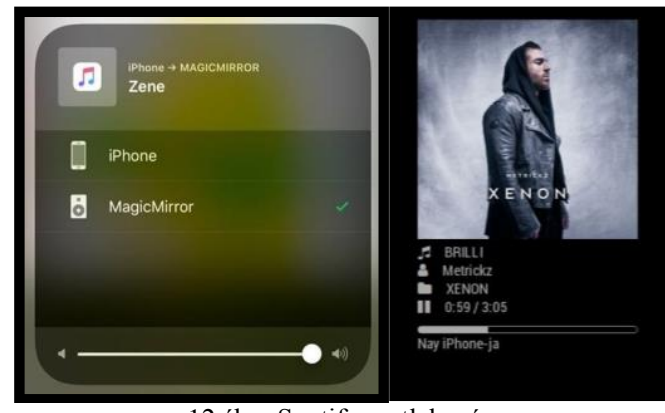

12.ábra Spotify csatlakozás

A Shairport [6] script segítségével tudunk a tükörre csatlakozni ezáltal a tükörbe épített hangszórókon szól a zene valamint a modul aktiválódása után megjelenik az aktuális zeneszám és a hozzátartozó borítókép valamint egyéb információk. A Smart Mirror-hoz, utólag került beépítésre USB -s hangszóró [21]. A YouTube Cast modul segítségével tudunk szintén telefonunkról valamint akár számítógépünkről YouTube alkalmazásból videót megnyitni a Smart Mirror közepére. A tesztek során Apple Iphone [22] volt alkalmazva, de Android Linux Os alatt is müködik [23].

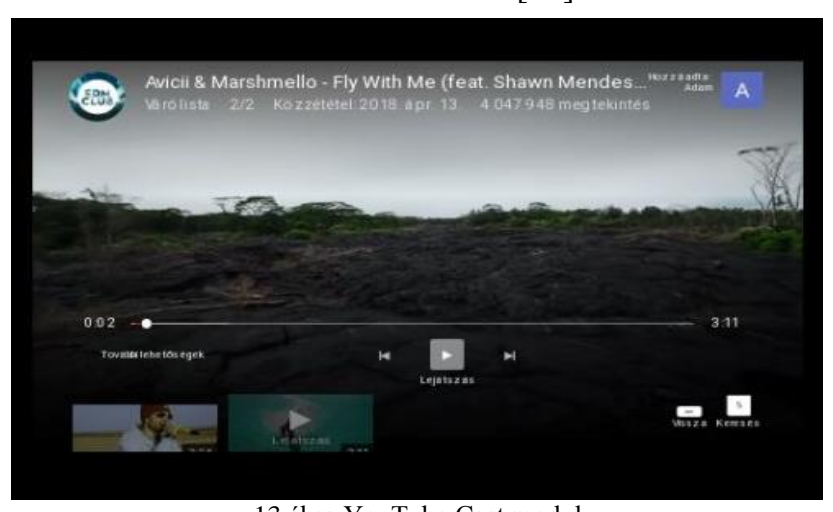

13.ábra YouTube Cast modul 


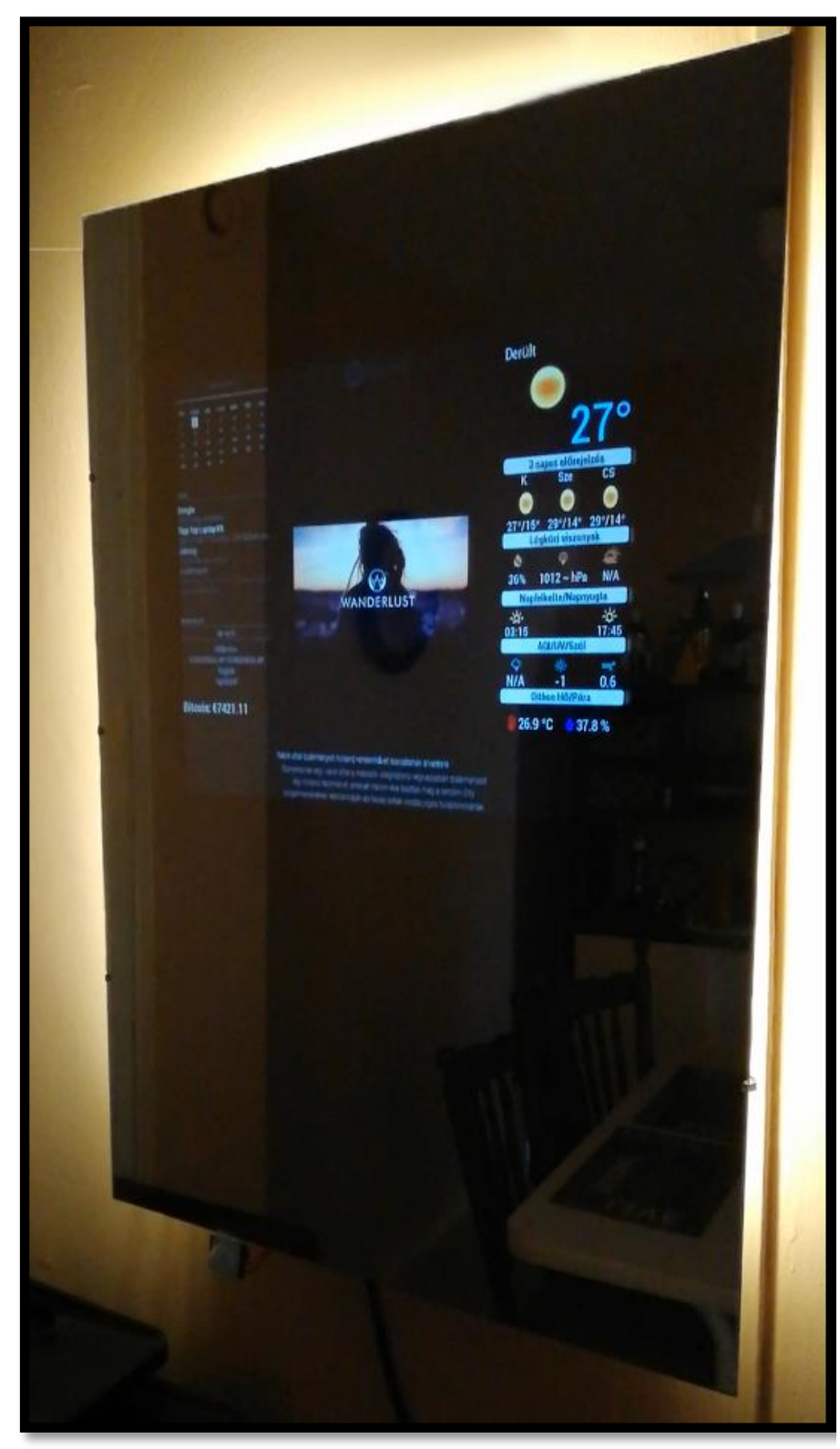

14.ábra Az elkészült intelligens tükör

\section{VI. ÖSSZEGZÉS}

A projekt befejezésével a Raspberry Pi 3 alapú SmartMirror megvalósításra került, a tesztelési folyamatot sikeresen lezajlott. A rendszer flexibilis és üzembiztos müködés biztosított a használat során. Az üzenetek olvasása és azok lekérése egyszerüen és praktikusan zajlik. A tükör platform független alapokon nyugszik, így bármitlen Os $-\mathrm{t}$ futtató okos telefonnal lehet csatlakozni rá.

\section{KÖSZÖNETNYILVÁNÍTÁS}

A publikáció elkészítését az EFOP-3.6.1-16-2016-00022 számú projekt támogatta. A projekt az Európai Unió támogatásával, az Európai Szociális Alap társfinanszírozásával valósult meg.
Recent Innovations in Mechatronics (RIiM) Vol. 5. (2018). No. SI. DOI: $10.17667 /$ riim.2018.si/28.

Köszönet illeti a Debreceni Egyetem Mechatronikai

Tanszékének oktatóit a rendelkezésre bocsátott segítségükért.

\section{HIVATKOZÁSOK}

[1] Innováció Magyarországon, (2017. 12. 01.). [Online]. Elérhető: http://www.napi.hu/tech/ezermilliardokat_hozhat_magyarorszagnak_az_ innovacio.631687.html

[2] Raspberry Pi 3, (2017. 11. 15.). [Online]. Elérhetö https://www.rpibolt.hu/Raspberry-Pi-3

[3] Raspberry Pi 3 teszt, (2017. 11. 15.). [Online]. Elérhető: https://malnapc.hu/2016/03/raspberry-pi-3-model-b-bemutatasa-esrovid-tesztunk/

[4] MagicMirror (2017. $11 . \quad 15$. https://magicmirror.builders/

[Online]

[5] RGB 5050 Led, (2017. 11. 15.). [Online]. Elérhető https://www.led24.hu/led-szalag/5050-smd-led-szalag/vled-led-szalag30-ledm-5050-smd-rgb-belteri

[6] Raspberry MagPi Magazine (2017. 12. 01). [Online]. Available: https://www.raspberrypi.org/magpi/

[7] Kéményrendszer (2017. 11. 15.). [Online]. Elérhető http://ezermester.hu/cikk-6196/Futeskorszerusites_es_kemenyfelujitas

[8] Z - profil (2017. 12.01). [Online]. Available: https://digitalbau.hu/arak/aluminium-profilok/aluminium-z profilok/aluminium-z-profilok

[9] IoT (2017. 12.01). [Online]. Available: https://www.invitech.hu/iot

[10] Raspberry Pi 3 (2017. 12. 01). [Online]. Available: https://www.raspberrypi.org/products/raspberry-pi-3-model-b/

[11] ASUS VW224T Monitor (2017. 12. 01). [Online]. Available: https://www.arukereso.hu/monitor-c3126/asus/vw224t-p38308089/

[12] DHT22 (2017. 12. 01). [Online]. Available: https://www.hestore.hu/prod_10036807.html/

[13] PIR sensor (2017. 12. 01). [Online]. Available: https://learn.adafruit.com/pir-passive-infrared-proximity-motionsensor?view=all

[14] Fritzing (2017. 12. 01). [Online]. Available: http://fritzing.org/home/

[15] VLC (2017. 12. 01). [Online]. Available: https://www.videolan.org/index.hu.html

[16] Wunderlist (2017. 12. 01). [Online]. Available: https://www.wunderlist.com/

[17] Bitcoin (2017. 12. 01). [Online]. Available: https://www.bitcoin.com/

[18] Spotify (2017. 12. 01). [Online]. Available: https://www.spotify.com/hu/

[19] YouTube (2017. 12. 01). [Online]. Available: https://www.youtube.com/

[20] Index (2017. 12.01). [Online]. Available: https://index.hu/

[21] Philips Speaker (2017. 12. 01). [Online]. Available: https://www.amazon.in/Philips-SPA-60-Speaker-SystemBlue/dp/B00TS1GWI6

[22] Apple Iphon (2017. 12. 01). [Online]. Available: https://www.arukereso.hu/mobiltelefon-c3277/apple/iphone-7-32gbp346175906/

[23] Zs. Molnár, T. I. Erdei, A. Husam, G. Husi, „Self-developed CNC prototype as IoT device," FMTÜ - XXII. International Scientific Conference of Young Engineers - Kolozsvár, 23-24.03.2017. 